\title{
Changes in Abscisic Acid, Carbohydrates and Nitrogenous Compounds of "Riesling" Grapevines during Induction of Second Shoots by Water-Deficit Stress
}

\author{
C. Kamande Ndung'U, Masumi Shimizu, Goro OKamoto and Ken Hirano \\ Faculty of Agriculture, Okayama University, Okayama 700, Japan
}

(Received June 30, 1995)

\begin{abstract}
Young "Riesling" grapevines were induced to produce second shoots by water stress before summer pruning. The vines, field-grown and established in isolated soil beds were subjected to water stress by disconnecting irrigation for 15 and 23 days. Water stress enhanced budbreak and cluster formation. In the early stage of water stress, abscisic acid (ABA) content increased in the canes and trunks, while it decreased in the roots. As the stress persisted, ABA content dropped in the canes and trunks, but increased in the roots. The levels of nitrogen, amino acids, and soluble sugars in the canes, trunks, and roots increased during water stress, while the levels of starch decreased. The results were discussed in relation to interactions of ABA with metabolism of amino acids and sugars. A high level of ABA during water stress was proposed to play a role in stimulating nutrient accumulation. A high reserve of nutrients, being available upon resumption of watering, was proposed to stimulate budbreak and subsequently to improve flower formation.
\end{abstract}

\section{INTRODUCTION}

The manipulation of growth cycles by induction of second shoots after summer pruning has been tested for some table grapes, such as "Kyoho" and "Ruby Okuyama" cultivars (Nakagawa, 1972 ; Takei, 1994) in Japan. Other studies have shown the effectiveness of water stress in inducing budbreak and improving fruitfulness in grapevines (Carbonneau and Casteran, 1979; Williams et al., 1991).

Hormonal and nutritional status are associated with dormancy and budbreak (Cutting et al., 1991; Emmerson and Powell, 1978). Levels of hormones and nutrients change in response to water stress (Andersen et al.,1995; Coombe and Monk, 1979). However, it is not clear whether such changes might influence budbreak following rewatering.

The present study was therefore conducted with two objectives: 1) to investigate the effectiveness of water stress before summer pruning in forcing new shoot growth in "Riesling" grapevines; and 2) to investigate the effects of water stress on the levels of hormones, carbohydrates and nitrogenous compounds in different parts of the vines, and their possible correlation with water-stress-induced budbreak.

\section{MATERIALS AND METHODS}

Plant materials: Thirty vines of 2-year-old "Riesling" on 5BB virus-free rootstock were used. The vines, field-grown under a polythene sheet covering at the experimental vineyard 
at Okayama University, were planted on raised beds which were lined with a polythene sheet under neath. After the commencement of new growth in spring, vines were well watered by drip irrigation to maintain the soil $\mathrm{pF}$ at $\leq 1.8$. Fertilizer was given twice a week through irrigation water using a complete liquid-fertilizer of the following compositicn per $100 \mathrm{~L}$ : $\mathrm{KNO}_{3}=27.0 \mathrm{~g}, \mathrm{Ca}\left(\mathrm{NO}_{3}\right)_{2} \cdot 4 \mathrm{H}_{2} \mathrm{O}=31.7 \mathrm{~g}, \mathrm{MgSO}_{4} \cdot 7 \mathrm{H}_{2} \mathrm{O}=16.7 \mathrm{~g}, \mathrm{NH}_{4} \mathrm{H}_{2} \mathrm{PO}_{4}=5.0 \mathrm{~g}$, EDTA$\mathrm{Fe}=1.5 \mathrm{~g}, \mathrm{H}_{3} \mathrm{BO}_{3}=0.3 \mathrm{~g}, \mathrm{MnSO}_{4} \cdot 5 \mathrm{H}_{2} \mathrm{O}=0.2 \mathrm{~g}, \mathrm{ZnSO}_{4} \cdot 7 \mathrm{H}_{2} \mathrm{O}=0.022 \mathrm{~g}, \mathrm{CuSO}_{4} \cdot 5 \mathrm{H}_{2} \mathrm{O}=0.005$ $\mathrm{g}, \mathrm{Na}_{2} \mathrm{MoO}_{4} \cdot 2 \mathrm{H}_{2} \mathrm{O}=0.002 \mathrm{~g}$. Two shoots per vine were allowed to grow and were all deflowered.

Water stress treatments and sampling: Water stress treatments were started from 16 July 1994, by disconnecting irrigation. The planting beds were covered with aluminium sheets to avoid any water penetration. Ten vines had their water disconnected for 15 days, and another 10 vines for 23 days. The non-stress control vines continued to receive normal irrigation throughout. At the end of the stress treatments, each shoot (cane) was pruned back to 6 nodes (buds). Control vines were pruned on 22 July 1994. All shoots were defoliated. Irrigation was resumed on the day of pruning.

Leaf- and stem-water potentials were measured at mid-day (11.00 to 13.00) by the pressure chamber method, as described by McCutchan and Shackel (1992). Measurements were done on leaves from nodes 5 to 8 . Soil samples (two per planting bed) were taken at mid-day with a cork borer, oven-dried to constant weight at $70^{\circ} \mathrm{C}$ for $72 \mathrm{~h}$, and their water content was determined.

At the end of stress treatments, two vines per treatment were sampled and separated into canes (current shoots), trunks and roots. The young second shoots induced following pruning of vines and resumption of irrigation were sampled one week after budbreak. Samples were immediately deep frozen in liquid $\mathrm{N}_{2}$, freeze dried and then ground to a fine powder. The samples were stored in darkness with silica gel till analysis.

Chemical analyses: Abscisic acid (ABA) was determined by GLC-ECD, with modifications of the method described by Robinson and Barritt (1990). One gram of sample was extracted 3 times with $80 \%$ methanol containing $0.3 \%$ ascorbic acid in darkness at $5^{\circ} \mathrm{C}$ for $24 \mathrm{~h}$. After evaporation of the methanol, the aqueous phase was extrated with ethyl acetate and 5\% sodium hydrogen carbonate. The residue remaining after drying in a centrifugal vaporizer (CVE-200D) was dissolved in methanol and spotted on a chromatography paper (Advantec 51B, $2 \times 40 \mathrm{~cm}$ ). Separation was done by ascending chromatography for $20 \mathrm{~cm}$ using isopropanol : $28 \%$ ammonia : water $(10: 1: 1)$ as a developing solvent system. ABA was recovered from $R f 0.8$ to $R f$ 1.0. The ABA was methylated with diazomethane using acetone-saturated $\mathrm{N}_{2}$ as a carrier. Two microliter aliquots were injected into a gas chromatograph (Shimadzu GC-3BE) equipped with ${ }^{63} \mathrm{Ni}$-election capture detector (ECD). The silica column was packed with $1 \%$ SE-30 Uniport HP, 80 to 100 mesh. Temperature settings were $220^{\circ} \mathrm{C}$ and $250^{\circ} \mathrm{C}$ for the column and injection port, respectively. Carrier gas was $\mathrm{N}_{2}$ at a flow rate of $45 \mathrm{ml} / \mathrm{min}$. ABA content was calculated using a linear equation generated from chromatographs of (+)-ABA, relating the area of ABA peak to ABA concentration.

Sugars and amino acids were extracted from $500 \mathrm{mg}$ sample with $80 \%$ ethanol at $70^{\circ} \mathrm{C}$. The supernatant obtained after centrifugation was evaporated and the residue was dissolved in $25 \mathrm{ml}$ of water. Ten milliliters of the aqueous solution was loaded in to a column of Amberlite CG-120 ion exchange resin, followed by $1 \mathrm{ml}$ of $0.1 \%$ pentaerythritol as an internal standard. The column was eluted with $50 \mathrm{ml}$ of water to release soluble sugars. Two milliliters of the eluate were freeze dried and the residue resuspended in $0.5 \mathrm{ml}$ pyridine, 0.25 $\mathrm{ml}$ hexamethyldisilizane, and $0.25 \mathrm{ml}$ trimethylchlorosilane, and heated at $60^{\circ} \mathrm{C}$ for $2 \mathrm{~h}$. Two microliter aliquots were injected into a gas chromatograph (Shimadzu GC-14A) equipped with a flame ionization detector (FID). 
Amino acids were released from the Amberlite column by eluting with $50 \mathrm{ml}$ of $2 \mathrm{~N}$ ammonium hydroxide. The eluate was evaporated and the residue was dissolved in $1 \mathrm{ml}$ of water. A five hundred microliter sample was mixed with an equal volume of lithium citrate buffer ( $\mathrm{pH} 2.2$ ) and filtered through a disposable syringe filter unit (cellulose acetate, $0.45 \mu \mathrm{m}$ ). Amino acids were analyzed in a fully automated amino acid analyzer (JEOL JLC-300).

The pellet that remained after centrifugation of the ethanolic extracts was oven-dried ( 60 ${ }^{\circ} \mathrm{C}$ ) and used for starch analysis. A fifty milligram sub-sample was incubated with $9.2 \mathrm{~N}$ and $4.6 \mathrm{~N}$ perchloric acid. Absorbance of derivatized reducing sugars was measured at $660 \mathrm{~nm}$ on a Hitachi 101 spectrophotometer. Reducing sugar equivalents were multiplied by 0.9 to obtain starch content.

Total and insoluble nitrogen were determined by a CN-coder (Yanako MT-600). One hundred milligrams of sample were used for total nitrogen, while the residue remaining after extraction of an equal weight of sample with $80 \%$ ethanol was used for insoluble nitrogen. Soluble nitrogen was calculated as a difference between total nitrogen and insoluble nitrogen.

Statistics: Data was subjected to analysis of variance as a randomized complete block design.

\section{RESULTS}

\section{Soil and vine water status}

The water content of well-watered soil ranged from 20 to $30 \%(w / w)$. After disconnecting irrigation, soil water content decreased rapidly, reaching $5 \%$ by the 5 th day of water cut-off. Leaf and stem water potentials ranged from -0.8 to $-1.6 \mathrm{MPa}$ for well-watered vines. In water-stressed vines, the values dropped to $-2.0 \mathrm{MPa}$ by the 5 th day of water cut-off. Water potential measurements could not be continued beyond the 5th day because the leaves had turned yellow.

\section{Budbreak and fruitfulness of second shoots}

Water stress enhanced budbreak and cluster formation, and the longer the duration of stress, the greater the effects (Table 1). Budbreak showed apical dominance in well-watered vines, being restricted to the uppermost 2 buds. Water stress was effective in overcoming this apical dominance tendency.

\section{Hormonal changes in the vines}

The 15-day water stress resulted in an increase of ABA contents of canes and trunks, but the levels in roots dropped. As the water stress persisted up to 23 days, the trend was reversed such that the ABA contents of canes and trunks dropped, while those of roots increased (Fig. 1).

\section{Nutritional changes in the vines}

Nitrogen contents of canes, trunks and roots increased in water-stressed vines (Table 2). Generally, the longer the duration of stress, the higher the nitrogen levels. Upon induction of second shoots, the young shoots of vines that had been waterstressed contained more nitrogen than those of well-watered vines.

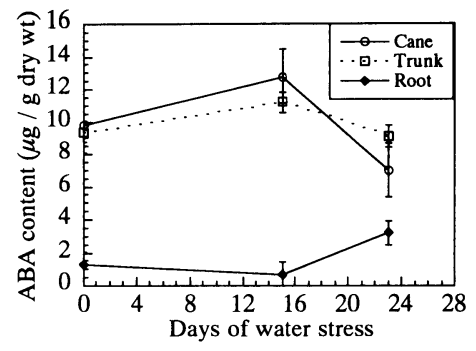

Fig. 1 Changes in abscisic acid (ABA) contents of parts of "Riesling" grapevines subjected to water stress before summer pruning. Vertical bars represent standard error at 5\% level. 
Table 1 Effect of water stress before summer pruning on budbreak and fruitfulness of the second shoots in "Riesling" grapevines.

\begin{tabular}{|c|c|c|c|c|c|c|c|}
\hline \multirow{2}{*}{ Treatment } & \multicolumn{6}{|c|}{ Budbreak (\%) per nodal position ${ }^{z}$} & \multirow[t]{2}{*}{ Clusters/shoot ${ }^{y}$} \\
\hline & 1 & 2 & 3 & 4 & 5 & 6 & \\
\hline Control & 0 & 0 & 0 & 0 & 58 & 96 & $1.5 \pm 0.5$ \\
\hline 15-day water stress & 0 & 0 & 14 & 64 & 93 & 100 & $1.7 \pm 0.2$ \\
\hline 23-day water stress & 25 & 44 & 35 & 69 & 75 & 75 & $1.8 \pm 0.3$ \\
\hline
\end{tabular}

${ }^{z}$ Buds are numbered from the base of the primary shoots.

y Values are mean \pm S.D.

Table 2 Total and soluble nitrogen contents (mg/100 mg dry wt) in parts of "Riesling" grapevines during induction of second shoots by use of water stress before summer pruning.

\begin{tabular}{|c|c|c|c|c|}
\hline \multirow{2}{*}{ Treatment } & \multicolumn{4}{|c|}{ Vine parts ${ }^{z}$} \\
\hline & Cane & Trunk & Root & Young shoots \\
\hline \multicolumn{5}{|l|}{ Control } \\
\hline Soluble N & 0.13 & 0.19 & 0.20 & 0.55 \\
\hline Total N & 0.54 & 0.53 & 0.93 & 3.95 \\
\hline \multicolumn{5}{|c|}{ 15-day water stress } \\
\hline Soluble N & 0.23 & 0.25 & 0.29 & 0.73 \\
\hline Total N & 0.78 & 0.68 & 1.42 & 4.57 \\
\hline \multicolumn{5}{|c|}{ 23-day water stress } \\
\hline Soluble N & 0.39 & 0.33 & 0.56 & 0.74 \\
\hline \multirow[t]{3}{*}{ Total N } & 0.80 & 0.69 & 1.57 & 4.27 \\
\hline & \multicolumn{4}{|c|}{ Significance $^{\mathrm{y}}$} \\
\hline & \multicolumn{2}{|r|}{ Treatments } & \multicolumn{2}{|r|}{ Vine parts } \\
\hline Soluble N & \multicolumn{2}{|r|}{$* *$} & \multicolumn{2}{|r|}{$* *$} \\
\hline Total N & \multicolumn{2}{|r|}{$*$} & \multicolumn{2}{|r|}{$* *$} \\
\hline
\end{tabular}

${ }^{2}$ Canes, trunks and roots were sampled at the end of water stress, when vines were pruned and watering resumed. Young shoots were sampled one week after budbreak.

y $*, * *$ Significant at $p \leq 0.05$ or 0.01 , respectively.

Similarly, water stress caused an increase of amino acids contents (Table 3). The increase was significant for arginine, aspartic acid and threonine. Glycine, threonine, arginine and glutamic acid were the predominant amino acids in canes. In trunks, glycine and threonine were predominant, while in roots, arginine and glutamic acid were predominant. In the newly induced second shoots, amino acids contents were higher in vines that had been water stressed than in well-watered vines. Glutamic acid and threonine were the predominant amino acids in the young shoots.

Starch contents of canes, trunks and roots decreased during water stress, but soluble sugars increased (Table 4). Roots contained more starch compared to trunks and canes. Moreover, after $23 \mathrm{~d}$ of water stress, canes and trunks contained more sugars but less starch, while roots contained more starch but less sugars. Newly induced second shoots contained more sugars but less starch, and the 23-day water stress elevated the sugar content of young shoots.

\section{DISCUSSION}

While soil water content decreased to a minimum after 5 days of irrigation cut-off, by which time most of the leaves had turned yellow, vines were able to withstand irrigation cut-off 
Table 3 Contents of amino acids ( $\mu \mathrm{mol} / \mathrm{g}$ dry wt) in parts of "Riesling" grapevines during induction of second shoots by use of water stress before summer pruning.

\begin{tabular}{lccccccccc}
\hline $\begin{array}{l}\text { Treatment and } \\
\text { vine part }\end{array}$ & ARG $^{\mathrm{y}}$ & ASP $^{\mathrm{y}}$ & GABA $^{\mathrm{y}}$ & GLU $^{\mathrm{y}}$ & GLY $^{\mathrm{y}}$ & PHE $^{\mathrm{y}}$ & THR $^{\mathrm{y}}$ & Others & Total \\
\hline Control & & & & & & & & & \\
$\quad$ Cane & 0.13 & 0.33 & 1.47 & 0.22 & 0.89 & 0.02 & 0.33 & 0.29 & 3.68 \\
$\quad$ Trunk & 0.08 & 0.25 & 1.25 & 0.07 & 0.32 & 0.02 & 0.17 & 0.16 & 2.32 \\
$\quad$ Root & 0.37 & 0.06 & 0.68 & 0.10 & 0.17 & 0.01 & 0.03 & 0.21 & 1.63 \\
$\quad$ Young shoots & 0.07 & 0.81 & 0.04 & 0.25 & 2.40 & 0.16 & 1.88 & 3.89 & 9.50 \\
15-day water stress & & & & & & & & & \\
$\quad$ Cane & 0.86 & 1.04 & 0.51 & 2.05 & 2.79 & 0.17 & 1.79 & 1.07 & 10.28 \\
$\quad$ Trunk & 0.37 & 0.65 & 0.45 & 1.45 & 3.35 & 0.70 & 1.92 & 2.11 & 11.00 \\
$\quad$ Root & 0.71 & 0.18 & 0.08 & 0.63 & 0.14 & 0.02 & 0.14 & 0.32 & 2.22 \\
$\quad$ Young shoots & 0.40 & 1.67 & 0.17 & 1.67 & 8.85 & 0.21 & 1.08 & 3.05 & 17.10 \\
23-day water stress & & & & & & & & & \\
$\quad$ Cane & 4.52 & 1.73 & 1.42 & 4.09 & 6.14 & 0.47 & 4.99 & 1.61 & 24.97 \\
$\quad$ Trunk & 0.80 & 1.08 & 0.85 & 0.69 & 3.72 & 0.27 & 1.90 & 3.06 & 12.37 \\
$\quad$ Root & 5.16 & 0.50 & 1.33 & 5.02 & 1.73 & 0.13 & 1.23 & 0.78 & 15.88 \\
$\quad$ Young shoots & 0.72 & 1.34 & 0.17 & 0.28 & 3.54 & 0.22 & 3.92 & 1.17 & 11.36 \\
\hline Significance & & & & & & & & & \\
$\quad$ Treatments & $*$ & $*$ & NS & NS & NS & NS & $*$ & & \\
$\quad$ Vine parts & $\mathrm{NS}$ & $*$ & NS & NS & NS & NS & NS & & \\
\hline
\end{tabular}

${ }^{z}$ Canes, trunks and roots were sampled at the end of water stress, when vines were pruned and watering resumed. Young shoots were sampled one week after budbreak.

y ARG, arginine; ASP, aspartic acid; GABA, $\gamma$-aminobutyric acid ; GLU, glutamic acid ; GLY, glycine ; PHE, phenylalanine; THR, threonine.

x NS, * Nonsignificant or significant at $p \leq 0.05$, respectively.

Table 4 Starch and soluble sugars contents (mg/100 mg dry wt) in parts of "Riesling" grapevines during induction of second shoots by use of water stress before summer pruning.

\begin{tabular}{|c|c|c|c|c|}
\hline \multirow{2}{*}{ Treatment } & \multicolumn{4}{|c|}{ Vine parts ${ }^{2}$} \\
\hline & Cane & Trunk & Root & Young shoots \\
\hline \multicolumn{5}{|l|}{ Control } \\
\hline Sugars & 1.3 & 1.4 & 1.0 & 3.4 \\
\hline Starch & 3.2 & 2.2 & 5.9 & 1.6 \\
\hline \multicolumn{5}{|c|}{ 15-day water stress } \\
\hline Sugars & 1.4 & 1.9 & 1.8 & 3.2 \\
\hline Starch & 1.4 & 1.4 & 6.8 & 2.6 \\
\hline \multicolumn{5}{|c|}{ 23-day water stress } \\
\hline Sugar & 2.5 & 2.3 & 2.0 & 4.4 \\
\hline \multirow[t]{3}{*}{ Starch } & 1.3 & 1.2 & 3.6 & 2.1 \\
\hline & \multicolumn{4}{|c|}{ Significance $^{\mathrm{y}}$} \\
\hline & \multicolumn{2}{|r|}{ Treatments } & \multicolumn{2}{|r|}{ Vine parts } \\
\hline Sugars & \multicolumn{2}{|r|}{$* *$} & \multicolumn{2}{|r|}{$* *$} \\
\hline Starch & \multicolumn{2}{|r|}{ NS } & \multicolumn{2}{|r|}{$* *$} \\
\hline
\end{tabular}

\footnotetext{
${ }^{z}$ Canes, trunks and roots were sampled at the end of water stress, when vines were pruned and watering resumed. Young shoots were sampled one week after budbreak.

y NS, $* *$ Nonsignificant or significant at $p \leq 0.01$, respectively.
}

for up to 23 days with positive results to budbreak and cluster formation. This shows that soil water status and vine foliar symptoms are unreliable indicators of water stress level in relation to budbreak induction. Enhancement of budbreak and inflorescence formation in "Riesling" 
grapevines by water stress agrees with the findings of Williams et al. (1991) on "Perlette" grapevines.

Planting vines on isolated soil beds made cutting off underground water from reaching the roots possible. Under this planting system, referred to as "restricted rooting volume culture" (Imai et al., 1991), disconnecting irrigation was effective in inducing water stress within a short time. Use of water stress for budbreak induction in vines under ordinary field planting would depend on a reliable dry period.

Response of ABA levels to water stress was dependent on duration of stress and the part of vine considered. During the early stages of water stress, ABA contents increased in canes and trunks but decreased in roots. As the stress continued, the trend was reversed, with ABA contents dropping in canes and trunks, and increasing in roots. This might be a suitable hormonal condition for budbreak after rewatering. ABA has been shown to play a role in bud regeneration and flower development in Citrus (Goldschmidt, 1980; Maggon and Singh, 1995).

Increase in $\mathrm{ABA}$ contents during water stress and correlations of $\mathrm{ABA}$ with dormancy have been reported (Emmerson and Powell, 1978 ; Robinson and Barritt, 1990). Water stress and ABA induce the synthesis of certain proteins in plants (Blackman et al., 1992; Bradford and Chandler, 1992). The role of these proteins (variously referred to as "stress proteins," "maturation proteins," "dehydrins," "responsive to ABA proteins") has been suggested to be mainly a protective one, enabling plant tissues to withstand desiccation and to reduce desiccation-induced cellular damage following rehydration.

Water stress caused increases in the contents of ABA, nitrogen and amino acids in "Riesling" grapevines. The results show that during water stress, nitrogen was remobilized from the senescing leaves to canes, trunks and roots. Glycine, threonine, arginine, and glutamic acid were the predominant amino acids during water stress. Arginine level is a good indicator of the nitrogen status of grapevines (Kliewer and Cook, 1971). Amino acids contents increased markedly in the xylem fluid of plum trees subjected to water stress (Andersen et al., 1995). Our findings support the idea of water stress- and ABA-induced amino acid accumulation and protein synthesis. The increased amino acids might serve as nitrogen storage compounds or as precursors of protein synthesis. This would subsequently promote budbreak and flower formation following rewatering.

Starch contents decreased, while soluble sugars increased during water stress. Increase in soluble sugars during water stress is important for osmoregulation (Andersen et al., 1995 ; Wang and Stutte, 1992). However, attention may also have to be focused on the high levels of sugars as a readily utilizable energy source, thus enhancing budbreak upon watering resumption. Several reports have shown ABA-mediated changes in sugars (Archbold, 1988 ; Ofosu-anim and Yamaki, 1994). The existence of an interaction between ABA and sugars in water stressed grapevines may not be ruled out.

The present study was conducted in early-summer, and bud dormancy at this stage can be classified as the para-type. It is well known that paradormancy is overcome by shoot tip removal, and even more readily if the leaves and lateral shoots are also removed (Mullins et al., 1992). Dormancy and budbreak are controlled by a complex interaction of water, hormones, and assimilates. It seems like water-stress-induced budbreak is a process under interactive control by hormones and nutrients.

In this research, the yield and quality of fruit borne on the second shoots were not determined. Further work should focus on these parameters and compare with the crop normally produced on primary (first) shoots, with emphasis on quality of the berries for wine production. 


\section{CONCLUSION}

The promotive effect of water stress on budbreak during paradormancy could be explained on basis of a hormonal and nutritional interaction. The role of increased ABA levels during water stress might be related to enhancement of nutrients accumulation. The high reserve of nutrients, being available upon resumption of watering, stimulated budbreak and subsequently improved flower formation. A second role of nutrient accumulation during water stress (especially amio acids and probably proteins, and sugars) might be related to the osmoregulation mechanism, thus protecting buds against desiccation damage.

\section{REFERENCES}

Andersen, P. C., Brodbeck, B. V., Mizell, R. F., III. 1995. Water stress- and nutrient solution-mediated changes in water relations and amino acids, organic acids, and sugars in xylem fluid of Prunus salicina and Lagerstroemia indica. J. Am. Soc. Hortic. Sci. $120: 36-42$.

Archbold, D. D. 1988. Abscisic acid facilitates sucrose import by strawberry fruit explants and cortex disks in vitro. HortScience 23 : 880-881.

Blackman, S. A., Obendorf, R. L., Leopold, A. C. 1992. Maturation proteins and sugars in desiccation tolerance of developing soybean seeds. Plant Physiol. 100 : 225-230.

Bradford, K. J., Chandler, P. M. 1992. Expression of 'dehydrin-like' proteins in embryos and seedlings of Zizania palustris and Oryza sativa during dehydration. Plant Physiol. 99 : 488-494.

Carbonneau, A., Casteran, P. 1979. Irrigation-depressing effect on floral initiation of Cabernet Sauvignon grapevines in Bordeaux area. Am. J. Enol. Vitic. 30 : 3-7.

Coombe, B. G., Monk, P. R. 1979. Proline and abscisic acid content of juice of ripe Riesling grape berries : effects of irrigation during harvest. Am. J. Enol. Vitic. 30 : 64-67.

Cutting, J. G. M., Strydom, D. K., Jacobs, G., Bellstedt, D. U., Van Der Merwe, K. J., Weiler, E. W. 1991. Changes in xylem constituents in response to rest-breaking agents applied to apple before budbreak. J. Am. Soc. Hortic. Sci. $116: 680-683$.

Emmerson, J. G., Powell, L. E. 1978. Endogenous abscisic acid in relation to rest and bud burst in three Vitis species. J. Am. Soc. Hortic. Sci. 103 : 677-680.

Goldschmidt, E. E. 1980. Abscisic acid in citrus flower organs as related to floral development and function. Plant Cell Physiol. 21 : 193-195.

Imai, S., Fujiwara, T., Tanaka, S., Okamoto, G. 1991. Effect of soil moisture on vine growth and fruit production of Kyoho grapes growing on restricted rooting volume. Environ. Control in Biol. 29: $133-140$.

Kliewer, W. M., Cook, J. A. 1971. Arginine and total free amino acids as indicators of the nitrogen status of grapevines. J. Am. Soc. Hortic. Sci. $96: 581-587$.

Maggon, R., Singh, B. D. 1995. Promotion of adventitious bud regeneration by ABA in combination with BAP in epicotyl and hypocotyl explants of sweet orange (Citrus sinensis L. Osbeck). Sci. Hortic. 63 : $123-128$.

McCutchan, H., Shackel, K. A. 1992. Stem-water potential as a sensitive indicator of water stress in prune trees (Prunus domestica L. cv. French). J. Am. Soc. Hortic. Sci. 117: 607-611.

Mullins, M. G., Bouquet, A., Williams, L. E. 1992. Biology of the Grapevine (1st ed.). Cambridge Univeristy Press, New York, p 93-96.

Nakagawa, S. 1972. Considerations in the adoption of forcing and all-year-round cultures in grape production. Agric. Hortic. $47: 875-879$ (in Japanese).

Ofosu-anim, J., Yamaki, S. 1994. Sugar content and compartmentation in melon fruit and the restriction of sugar efflux from fresh tissue by ABA. J. Jpn. Soc. Hortic. Sci. 63 : 685-692.

Robinson, T. L., Barritt, B. H. 1990. Endogenous abscisic acid concentrations, vegetative growth, and water relations of apple seedlings following PEG-induced water stress. J. Am. Soc. Hortic. Sci. 115 : 991-999. 
Takei, K. 1994. The effects and considerations of postharvest pruning on glasshouse forcing of grapevines. Yamanashi no Engei 5 : 34-38 (in Japanese).

Wang, Z., Stutte, G. W. 1992. The role of carbohydrates in active osmotic adjustment in apple under water stress. J. Am. Soc. Hortic. Sci. 117 : 816-823.

Williams, L. E., Neja, R. A., Meyer, J. L., Yates, L. A., Walker, E. L. 1991. Postharvest irrigation influences budbreak of "Perlette" grapevines. HortScience 26: 1081.

\section{〈和文抄録〉}

\section{水分ストレスが“リースリング”ブドウ樹の ABA，窒素および 炭水化物栄養の変化と 2 番枝の発育に及ぼす影響 \\ C. K. ドゥング・清水ますみ・岡本 五郎・平 野 健 \\ 岡山大学農学部}

地表と隔離したベッドに植えた“リースリング”の幼樹に，7 月中旬から 15 日または 23 日間, かん水を中断して水分ストレスを与えると, 夏季剪定後の 2 番枝の発芽と花穂の着生が促進され た. ストレス 15 日目には母枝の ABA 含量は低下し, 根では增加した. また, ストレスが進むにつ れて, 樹体各部の全窒素とアミノ酸, 糖含量が著しく増加し, デンプン含量が減少した。これらの 結果から, 水分ストレスによって増加した ABA は養分の蓄積を促進したと考えられ, この養分蓄 積が剪定後の 2 番枝の発芽と花穂の発育を良好にしたと推察される. 